\title{
Globalization and Intercultural Management
}

\author{
Ruxandra Georgescu \\ gruxandra11@,yahoo.ro \\ Gabriela Daniela Bulacu \\ Claudia Istratie (Achim) \\ veronique claudia@yahoo.com \\ Valahia University of Targoviste, Romania
}

\begin{abstract}
Nowadays the intercultural management has become very important because the interaction between managers and employees is very important in the development of the organization. We have to know that the globalization, a concept that has become more and more present in current economic and political literature, implies the formation of a new world economic hierarchy, which deviates from the traditional models of capitalism and requires a new institutional framework. For workers, globalization means the possibility of working abroad. For investors, it can mean the ability to transfer capital from one country to another, from one day to the next. From the abundance of information that invades us daily through modern ways of communication, it has been evocative terms such as: international (multi-national), multinational (a certain number of nations), transnational (beyond national borders) or development global (the whole world). This article want to show the link between globalization and management.
\end{abstract}

Key words: interculturality, management, organization, globalization.

JEL Classification Codes: M1.

\section{Introduction}

The environment in which organizations operate is becoming more turbulent, so organizations need to learn to adapt quickly to changing environmental conditions.

In a globalized economic environment, understanding the structures and norms underlying the operation of the system and the economic entities is of the utmost importance for a more efficient operation of the company.

Within this environment, there are two diametrically opposite trends, equally important: globalization and localization. The uneven development of economic globalization and social globalization, which takes place at a slower pace, highlights the importance of the local plan. The process of articulating the individual to a system of common norms and its cultural orientation in terms of organizational culture is given by the cultural link to the place, region or nation.

The world economy is constantly expanding, the contact between the various economic entities becoming more and more acute. Intercultural management has become a concept in recent years not only in management practice, it is integrated into university studies and programs, but also a reflection for many international companies.

\section{The Global Challenge}

Every day we hear it on the news, read it in the papers, overhear people talking about it, and in every single instance the word "globalization" seems to have a different meaning. So, what is globalization?

At the political and economic level, globalization is the process of denationalization of markets, politics and legal systems; it is the rise of global economy. At the business level, the process of globalization is when companies decide to take part in the emerging global economy and establish themselves in foreign markets. They adapt their products or services to the linguistic and cultural requirements of different nations. Then, they might take advantage of the Internet revolution and establish a virtual presence on the international marketplace. E- 
commerce has changed traditional business practices by providing direct international access to information and products.

Whatever their industry or country of origin, all companies are facing the same challenge to a greater or lesser degree: globalization. It is becoming more and more evident that companies need to plan ahead and anticipate coming developments if they are to be successful in the future. Ecological matters have gained in importance at the turn of the century. Climate change is perceived as the biggest challenge to mankind and affects all industries and societies alike (Stern, 2008, p. 1).

In the past, it was primarily reductions in tariff and trade barriers that stimulated global trade and encouraged the integration of international business. Today, however, the key factor is the global networking that has been made possible by new communication technologies.

Increasingly intense international competition is accelerating structural change throughout the world. More and more, industries that only "yesterday" limited their production to the United States, Europe or Japan are feeling the influence of threshold countries. Moreover, jobs that seemed guaranteed for life some years ago are moving into these low-wage countries. No longer are they limited to the production of simple toys for children - today companies in threshold countries are producing luxury consumer goods, consumer electronics and highly sophisticated machines and vehicles, and with dizzying success (Lippisch/Köppel, 2007, p. 3).

In order to be economically successful in the global market, it is not only the hard facts that count - such as the general economic and commercial settings, product quality or innovative products and services. "Soft" competencies, especially social competence and excellent communication skills, become more and more important. Thus, a balanced consideration of hard facts and "soft" competencies is increasingly becoming a prerequisite for global success. Only companies and organizations with a multicultural structure will succeed beyond the regional level and will continue to be successful on a global scale. In the future, mono-structures and monocultures will be limited to regional importance. However, multicultural organizations will not prosper automatically, just because they are multicultural. On the contrary, if managed badly, they may function worse than mono-cultural organizations. Thus, the skills to lead a multicultural organization have to be in the focus and are paramount for the success in the global market.

These consequences of global competition are putting pressure on companies in the developed Western countries. Companies from Central and Western Europe are faced with the question of how to respond in order to remain competitive. Market isolation is a strategy that no longer works in today's globalized world, and it is likely to do more harm than good.

Instead, today it is crucial to establish a solid competitive position in the global arena and to defend that position by continually adapting to meet the needs of the market. There is no doubt that a corporate culture that is open to innovation and shaped by global thinking plays a key role in this context, a culture in which representatives of different countries and cultures can come together, while giving due regard to the developments and conditions that influence a company's actions (Lippisch/Köppel, 2007, p. 3). International business and professional activity demand movement beyond one particular cultural conditioning into a transcultural arena.

The technological environment surrounding businesses today is characterized by a soaring speed of change and innovation. Revolutionizing innovations in the fields such as microelectronic, robotic and generic engineering can be perceived as a threat or chance to the enterprise's competition (Welge/Al-Laham, 2008, p. 295).

If globalization refers to the transmission of ideas, meanings and values across world space the intercultural aspect is obvious. In the contemporary period, and from the beginning of the twentieth century, this process is marked by the common consumption of cultures that have been diffused by the Internet, popular culture media, and international travel. This has added to processes of commodity exchange and colonization which have a longer history of carrying cultural meaning across the globe. The circulation of cultures enables individuals to partake in extended social relations that cross national and regional borders. The creation and expansion of such social relations is not merely observed on a material level. Cultural globalization involves the 
formation of shared norms and knowledge with which people associate their individual and collective cultural identities. It brings increasing interconnectedness among different populations and cultures (Steger/James, 2010, p. 12).

As far as global challenges are concerned, the current developments can be split into four main categories (Rothlauf, 2004, pp. 25ff), namely:

- new technologies

- new markets

- new environmental drivers

- new global players

Within this framework, an intercultural answer has to be given, which includes:

- new corporate culture

- new skills

- new management and working styles

- new company structures

Both, challenges and the intercultural answers will be presented in the following and are also illustrated in Fig. 1.1.

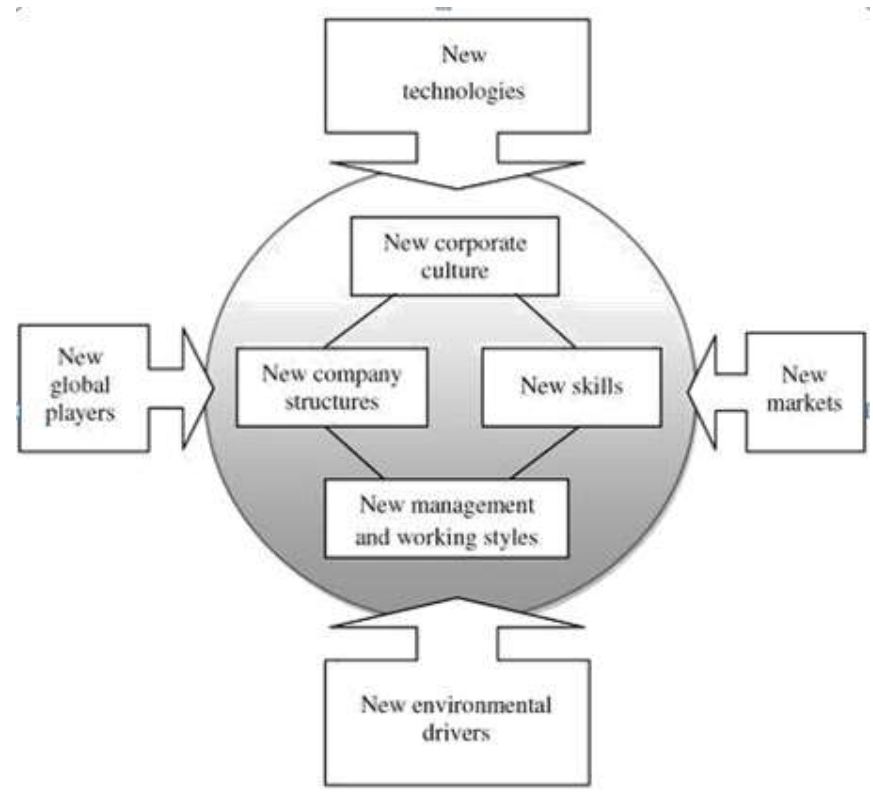

Fig. 1.1: Challenges and solutions in the global context

Source: Jürgen Rothlauf, A Global View on Intercultural Management, 2014, page 38

\section{Global challenges}

New technologies

New information and communication technologies, such as the internet, are ubiquitous and cheap; they control the markets, permit worldwide access to information, foster global trends and reach the most distant corner of the world.

Moreover, an emerging technology as distinguished from a conventional technology is a field of technology that broaches new territory in some significant way with new technological developments. Examples of currently emerging technologies include educational technology, nanotechnology, biotechnology, cognitive science, robotics, and artificial intelligence.

\section{New markets}

Business is always changing and to maximize the relevant business options one have to explore new markets and to expand the current buiness activities. As resources become scarcer 
and scarcer and domestic markets are reaching the saturation point, it is becoming increasingly important to open up new sales, resource and labor markets. A successful search for geographic or technical alternatives is part of a company's international strategy. Moving into new territories and categories is a radical strategy that can create major potential for incremental business growth. To succeed it requires a precise understanding of market dynamics, consumer behaviour and the competitive landscape of the specific markets.

New global players

Companies from threshold countries are developing at a breathtaking speed. They have the benefit of a plentiful supply of cheap, motivated and well-qualified workers. They are developing an increasingly accurate sense of where the demand is, and their ability to offer highquality products at a reasonable price is growing as well.

A good example for those new global players is BRICS, an acronym for an association of five major emerging national economies: Brazil, Russia, India, China and South Africa. The BRICS members are all developing or nearly industrialised countries, but they are distinguished by their large, fast-growing economies. Moreover more and more developing countries are now entering the international stage and will play a larger role in the future.

\section{New environmental drivers}

Climate change and energy supply concerns are the primary drivers in the present debate. It has now been scientifically proven that climate change is triggered off by the emission of anthropogenic greenhouse gases; first and foremost CO2. In order to find adequate solutions to meet the manifold environmental need an urgent global response is demanded. The growing pollution all around the world has to be taken into account and the focus of all business activities should move to a higher environmental commitment of all parties involved in this context. In the long run, only those enterprises will survive that have the right answer in this very challenging field and can offer environmentally friendly products and services.

\section{The intercultural answer}

Given the variety of challenges, the solution must vary as well. Apart from technological solutions, a specific view on the so-called soft factors enables us to get a better understanding of how the problems can be solved in the future (Lippisch/Köppel, 2007, p. 8).

\section{New company structures}

Among the ways in which companies seek enhanced flexibility to meet the challenges of increasingly volatile markets are the outsourcing of certain services that were not marketable in the past. This market-driven increase in flexibility needs to be applied at the operational level; corporate structures as well as management methods need to be adapted to meet the needs of the future.

\section{New management and working styles}

The push towards increasing flexibility, accompanied by an increasing acceptance of personal responsibility continues in processes at the human level: decentralization, fluid company borders, globally organized added value and constant change require alterations in management and work models as well. The relevant demands must be taken into account in employment relationships, work-hour arrangements, incentive systems and further training programs, especially intercultural training programs.

Global managers work with people who have very different ideas about how business gets done. They must understand and adapt to country differences in unions, corporate governance, political legislation, investment policies etc. that can have an impact on business. 
Moreover, global managers have to be fully aware of the complexity of norms, beliefs, values and attitudes that distinguish one cultural group from another. Working globally, managers must address multiple and differing expectations about how people (employees, colleagues, customers, suppliers, distributors, etc.) should behave, and how work should get done. Given the cultural diversity of our world, this is an extremely challenging task and requires a new thinking as far as the relevant working style is concerned. Today's leaders need to adapt to leading and managing people of different cultures. Cultural differences impact everything from interpersonnel communication to health and safety procedures to project management. In short, no corner of any business escapes.

New skills

In globally active companies it is becoming more and more important that each employee shows personal initiative; they also need to be able to adapt their tasks to the changing demands within and outside the company, in order to meet the challenges of global business. Economically-driven diversity management is one way of ensuring that the various available human resources are used and combined in a manner appropriate to the specific situation.

As with all businesses success depends upon effective cooperation and communication within a company, particularly within multicultural teams. Therefore, business structures have to be radically transformed in the given context. Changes in areas such as communication and information technology and shifts towards global interdependence are obvious and having resulted in companies that are becoming increasingly international and as a logical consequence more and more intercultural.

\section{New corporate culture}

A global mindset and an innovative spirit should be made an integral part of the company and its corporate culture. Executives and employees, who understand global contexts and the need for innovation as well as its consequences for their own behavior, are crucial for establishing such a corporate culture. Furthermore, a company's leadership has a responsibility to encourage, communicate and implement a continuously developing corporate culture with a specific focus on newly formed multicultural teams. Establishing and implementing ethical principles constitutes a major challenge in this context - all the more so because such principles need to be internationally applicable, binding and intercultural accepted.

\section{"The magic in the globalization of the last years is the mixture of different cultures."}

(Matthew Emmen)

\section{Intercultural management}

The economic globalisation, the technological progress and the revolution of the information and communication technology sector have facilitated the communication among people around the world. While the psychology and sociology have reacted by studying the relations deriving from cultural exchanges, the economy developed a new discipline in the 1970s - the intercultural management - aimed at adapting the marketing rules to the specific cultural characteristics of a target market. Since then, the scope and object of study have been expanded to include the management at the level of organisations operating in a multi-cultural environment, especially for companies operating branches outside the country of origin. Consequently, the intercultural management has rapidly developed the notions of mother-culture versus enterprise-culture. The first element is specific for the country from which the company originates, while the second is specific for the country in which the company opens its branch. In order to avoid possible cultural conflicts, the intercultural management uses specific tools and methods that mediate between two or more cultures. 


\section{Definition of intercultural management}

Intercultural Management can be described as a combination of knowledge, insights and skills which are necessary for adequately dealing with national and regional cultures and differences between cultures at several management levels within and between organisations (Burggraaf, 1998). It is not a separate subject but an integral part of general and international management.

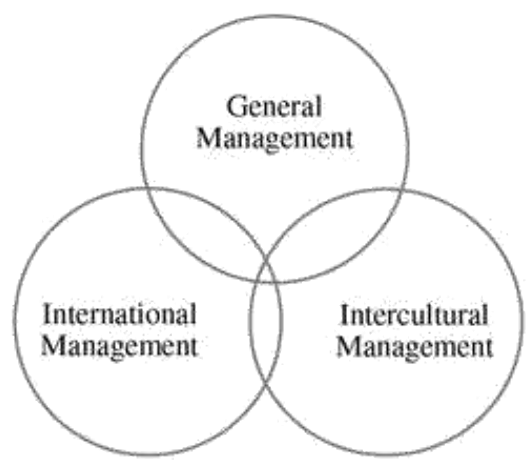

Fig. 1.2: Management interrelations

Source: Jürgen Rothlauf, A Global View on Intercultural Management, 2014, page 51

Intercultural Management interleaves with international management as some similarities occur. It might therefore be relevant to depict those features of international management that are effective. These features are:

- Teams consist of internationally representative managers

- Structural forms such as organic modes exist

- Leadership includes varied skills appropriate for the global context

- Motivation is appropriate for diversity

- Organisational cultures such as those characterising learning organisations exist

- Communication methods and systems are available and applicable

- Human resource management systems and practices that reflect the dynamic of operating in the global context are used (Jacob, 2003)

As part of the term intercultural management the expression management is ubiquitous. Management is the on-going professional composition, steering and development of (complex) structures and processes in order to achieve the goals of the organisations. (Koch, Speiser, 2008).

For a definition of intercultural management the general management definition needs to be extended by the cultural component. Therefore, intercultural management can mean to achieve goals with professional means by persons of other or different cultural influence. It is the composition, steering and development of structures and processes in order to achieve the goals of an organisation in a context that is shaped by the coincidence of at least two different cultures. (Koch/Speiser, 2008)

\section{The importance of intercultural management}

If you agree with Elashmawi/Harris (1993, p. 1), who say that "the new world market will not only be international, but intensely intercultural", it will become obvious that the international management of the future will also - or even particularly - make the inclusion of intercultural management an absolute necessity. Hambrick/Snow (1989, pp. 84ff) arrive at a similar conclusion and say: 
"Integration and human resource management are dependent upon one another to the degree that structuring a firm's global activities involves the deployment and use of human capital and other human aspects."

The need for a specific intercultural discipline in the management field comes from the fact that speaking a foreign language is not enough for a sufficient communication between people belonging to different cultures. The surface of a process is much more complex than the simple understanding of what the other says. This is because the communication is not linear, which means that the transmission of a message is never neutral; the spoken message transmits words and notions, but also norms and values and some of these norms and values may not be fully shared by the dialogue partner.

Consequently, managers have to be aware not only of the different language of the business partner but their diverging attitude, time perception, behaviours, traditions and further aspects related to a different culture. At this point, intercultural management provides the opportunity to be aware of it and deal with such cultural aspects. Failures in one's behavior while doing business or misunderstandings of the business partners' actions can lead to severe problems and even a termination of the partnership.

In recent years, the intercultural management has become particularly important as the phenomena of globalisation has been accompanied by increasing migration flows, enlargement of the European Union, economic openness of many countries around the world, the emergence of new economies like China and the expansion of economic partnerships between countries disposing of different economic systems. The cooperation between these different economic systems, which are based on significant cultural differences, requires a new - intercultural approach.

Another possibility of integrating intercultural thinking and acting into the existing curriculum can be seen in the job enlargement of international personnel management. Especially in Anglosaxon literature (Black/Mendenhall, 1990; Phatak, 1997; Teagarden/Gordon, 1994; Tung, 1981), strong reference is to be found.

The authors share the opinion that "these new roles include international extensions of more traditional human resource management support functions such as providing country-specific knowledge of union and labour policies, legal and regulatory requirements, compensation, and benefit practises. They include preparing people for international assignments, and re-entry after those assignments are completed." (Teagarden/Glinow, 1997, p. 8)

For companies, this approach means that the consideration of the intercultural issues of all cross-border activities must no longer be neglected. Far more than before, these issues have to explicitly find their way into the respective activity's intercultural orientation. (Perlmutter, 1965, p. 153)

Those who want to succeed on international markets have to deal with unprecedented problems, which result due to the mere fact that there is contact with foreign countries, cultures as well as economic and social structures. However, an explicit implication of those factors does not happen in most cases. At this point, intercultural management comes into place.

At the University of Applied Sciences Stralsund, a study was conducted by the four students Carolin Boden, Elisabeth Guth, Nelly Heinze and Sarah Lang, who questioned 22 consulting companies and experts about the influence of cultural aspects on the failure of mergers and acquisitions (M\&A). The results underline the importance of intercultural management and training during the M\&A process, but can be transferred to other fields as well. 


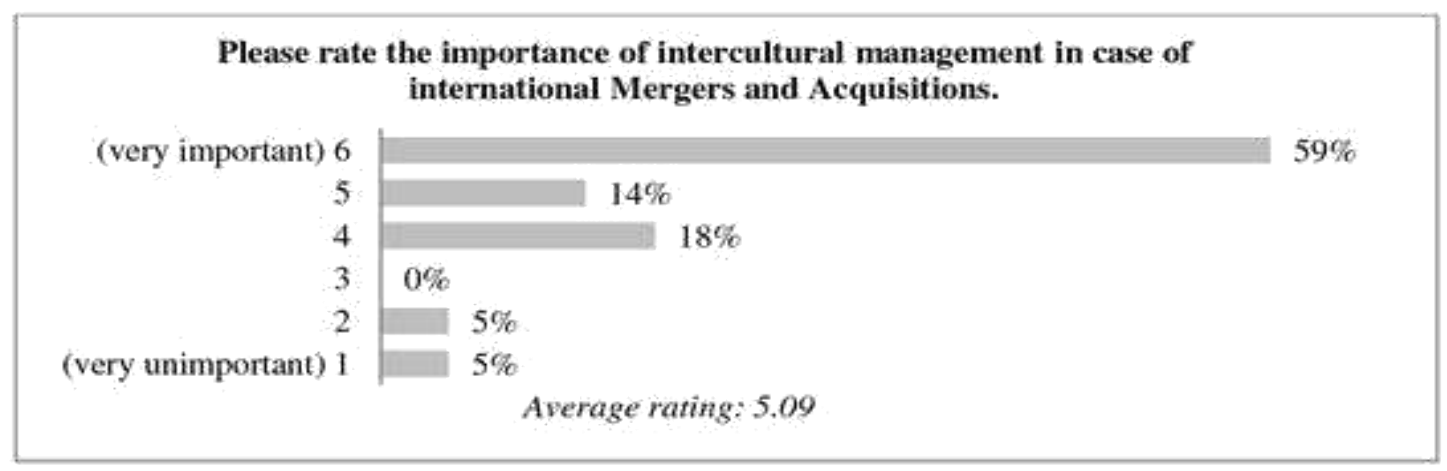

Fig. 1.3: Importance of intercultural training for international M\&A Source: Boden/Guth/Heinze/Lang, 2011, p. 81

\section{Conclusions}

The discussion, whether the topic of management has to be seen in a "culture-bound" (hypothesis by culturalism respectively cultural relativists) or "culture-free" context (hypothesis by Universalists), has shown that the majority - according to Hofstede (1993) - considers management as a culture-bound phenomenon. Hence, a particular sensibilization for cultural phenomena is required. (Kumar, 1988, pp. 389ff, Kiechl, 1997, p. 16)

While a few scientists (Thomas, 1996; Kiechl, 1990) have pointed out a global convergence and have consequently ruled out a connection between ethno culture and corporate culture, the majority of scientific studies (Adler, 1983; Perlmutter, 1965; Hofstede, 1993) verify that undertakings in different nations reveal different corporate cultures, which can be traced back to the respective ethno cultures. At internationally active companies, the ethno cultural influence on the corporate culture, which depends on the nature of the relationships between the subsidiaries and the parent company and between the different subsidiaries, can be monitored and to a certain degree even steered (Kiechl, 1997, p. 14).

One can conclude that the task of intercultural management includes the concrete design of functional, structural and personnel management processes. Its aim is to facilitate a successful overcoming of management problems by providing adequate approaches for efficient international actions. (Perlitz, 1995, p. 318) Therefore, professionals and executives of internationally operating companies do not only need legal, technical and economic expertise and speak foreign languages but also have to adjust their behavior to intercultural standards which enable them to work effectively in a foreign environment.

Whoever wants to remain internationally successful has to be able to assess anticipatorily the impacts of cultural differences on management practices, individual work attitudes, communication, the conduct of negotiations etc. (Weidmann, 1995, p. 41) However, this way of thinking may not be seen as a one-way street. The necessity to observe and apply intercultural principles and behavior is not only vital for external business relations but also for internal business processes.

In future, one can assume that the number of business meetings where participants come from different cultural backgrounds will increase (Mauritz, 1996, p. 1). For German companies, this development means that they will have to integrate more employees from other cultures into the company - regardless whether they work at the corporate head office or at foreign subsidiaries. The new questions and solution approaches involved are also part of intercultural management.

\section{References}

1. Adler, N.J., A Typology of Management Studies Involving Culture, in: Journal of International Business Studies, Nr. 6/1983.

2. Black, J.S./ Mendenhall, A., Cross-cultural Training Effectiveness: A Review and a Theoretical Framework for Future Research, in: Academy of Management Review, Nr. 15,1990. 
3. Boden, C./Guth, E./Heinze,N./Lang,S., Results of a study on Intercultural Aspects of M\& A, Stralsund 2011 (unpublished).

4. Burggraaf, W., Intercultural Management, in: Nyenrode University (ed.), June, Buschermöhle, 1998

5. Elashmawi F./ Harris, P.R., Multicultural Management, New Skills for Global Success, Houston 1993.

6. Hambrick, D.C./Snow, C.C., Strategic Reward Systems, in: Snow (Hrsg.), Strategy, Organization Design and Human Resource Management, Greenwich 1989.

7. Hofstede, G., Interkulturelle Zusammenarbeit - Kulturen, Organisationen, Management, Wiesbaden 1993.

8. Jacob, N., Intercultural Management, 1sted., London 2003

9. Koch, E., Interkulturelles Management. Konstanz/München 2012.

10. Kopper/Kiechl (Hrsg.), Globalisierung: Von der Vision zur Praxis, Zürich 1997.

11. Kumar, B. N., Konzeptioneller Rahmen, in: Kumar, B. N./Wagner, D., Handbuch des Internationalen Personalmanagements, Verlag C.H. Beck, München 1998.

12. Lippisch, S./Köppel, P., Key to Company's competitiveness: The Ability to Innovate and Cooperate on a Global Level, in: Bertelsmann Stiftung (Hrsg.), Globalization and Change, Gütersloh 2007.

13. Matthews, S., Trends in Managing Mobility, in: Personalwirtschaft, 07/2007.

14. Maurits, H., Interkulturelle Geschäftsberiehungen: Eine interkulturelle Perspektive für das Marketing, Wiesbaden 1996.

15. Perlitz, M., Internationales Management, 2nd edition. Stuttgart 1995.

16. Perlmutter, H., L'Enterprise International. Trois Conceptions, in: Revue Economique Sociale, $23 \mathrm{Jg}$., Nr. 2/1965.

17. Phatak, A., International Management. Concepts and Cases, Cincinnati, Ohio 1997. Pinzler, P., Moral statt Markt, in: Die Zeit, Nr. $49 / 1994$.

18. Rotblauf, J., Total Quality Management, 2nd ed,. München 2004.

19. Steger, M.B, James, P., Ideologies of Globalism, in: Globalization and Culture: Vol. 4, London, 2010

20. Stern, N., The Economics of Climate Change: The Stern Review, March 2008.

21. Teagarden, M.B./ Glinow von, M.A., Human Resource Management in Cross-Cultural Contexts, in: Management International Review, 1/1997.

22. Teagarden, M.B./ Gordon, G.G., Global Human Resource Management: Corporate Selection Strategies and the Success of International Managers, in Selmer (Hrsg.), Expatriate Management: New Ideas for Business, New York 1994.

23. Thomas, D./Ely, R., Making differences matter: a new paradigm for managing diversity, in: Harvard Business Review, September-October 1996.

24. Tung, R.L., Selection and Training of Personnel for Overseas Assignments, in: Columbia Journal of World Business, Nr. 16/1981

25. Unternehmenskultur, in: Lattmann, C. (Hrsg.), Die Unternehmenskultur: ibre Grundlagen und ibre Bedeutung für die Führung der Unternehmung, Heidelberg 1990

26. Weidmann, W.F., Interkulturelle Kommunikation und nationale Kulturunterschiede in der Managementpraxis, in: Scholz, J.M. (Hrsg.), Internationales Change-Management, Stuttgart 1995.

27. Welge, M./Al-Laham, A., Strategisches Management: Grundlagen - Prozess - Implementierung, 5th ed., 2008. 